DEPARTMENT OF THE INTERIOR

UNITED STATES GEOLOGICAL SURVEY

OCCURRENCES OF LEAD MINERALS IN ALASKA

Compiled by

Edward H. Cobb

Open-File Report 83-73

1983

This report is preliminary and has not been reviewed for conformity with U.S. Geological Survey editorial standards. 
The following references give data, as of July 1, 1981, on localities where lead minerals have been found in Alaska. References are keyed by number to locations shown on the accompanying map. An asterisk ( $*$ ) preceding a locality name indicates recorded production.

In most instances the report(s) cited for each occurrence is a summary of data in older reports and was compiled since 1975. Most of the summary reports contain lists of the reports used in their compilation. Citations are in standard bibliographic format with the exception that each containg, in parentheses, an abbreviation for the report or map series and the number of the report or map. Abbreviations used are: AOr, State of Alaska Division of Geological and Geophygical Surveys Open-File Report; BMOF, U.S, Bureau of Mineg Open-File Report; C, U.S. Geological Survey Circular; GR, State of Alaska Division of Mines and Geology Geologic Report; MF, U.S. Geological Survey Miscellaneous Field Studies Map; OF, U.S. Geological Survey Open-File Report. 
1. Lik: Cobb and others, 1981 (OF 81-767A), p. A11

2. Hot Dog: Cobb and others, 1981 (OF 81-767A), P. AII

Unnamed prospect: idem, P. Al3

3. Red Dog: Cobb and others, 1981 (OF 81-767A), P. Al2

4. Ginny Creek: Cobb and others, 1981 (OF 81-767A), o. A16-A17

5. Drenchwater Creek: Cobb and others, 1981 (OF 81-767A), P. A14-A15

6. Story Creek: Ellersieck and others, 1982 (C 844), p. 35-38

7. Whoopee Creek: Ellersieck and others, 1982 (C 844), p. 35-38

8. Isikut Mountain: Jansons and Parke, 198! (BMOF 26-81), p. 117-120

Riviliktort Hountain: idem, p. 138-143

9. Koiyaktot Mouncains: Jansons and Parke, 1981 (BMOF 26-81), p. 122-131

10. Unnamed occurrences: Detra, 1977 (OF 77-223), areas A, B

11. Occasional: Grybeck, 1977 (OF 77-I66C), P. 32, loc. 2

12. Esetuk Glacier: Cobb and otherg, 1981 (OF 81-767A), 9. A18

13. Arey Creek tributary: Cobb and others, 1981 (OF 81-767A), P. Al3

Unnamed occurrence: idem, P. A2l

14. Bear Mountain: Cobb and others, 1981 (OF 81-767A), P. A23

15. Hunt Creek: Cobb and Miller, 1981 (OF 81-847A), p. Al0

16. Howk River: Cobb and Miller, 1981 (OF 8I-847A), P. Al2

17. Jade Mountains: Cobb and Mayfield, 1981 (OF 81-570A), P. A6

18. Unnamed occurrence: Cobb and Mayfield, 1981 (OF 81-570A), P. A10

19. Kaluich area: Cobb and Mayfield, 198I (OF 8I-570A), P. A6

20. Imelyak River: Cobb and Mayfield, 1981 (OF 81-570A), P. A5-A6

21. Unamed occurrence: Cobb and Mayfield, 1981 (OP 81-570A), P. Al2

22. Unmamed prospects and occurrence: Cobb and Mayfield, 1981 (OF 81-570A), p. A11-A12

23. Shishakshinovik Pass: Cobb and Mayfield, 1981 (OF 81-570A), D. A9

24. Aurora Mountain: Cobb and Mayfield, 1981 (OF 81-570A), p. 44

Ruby Creek (Bornite): idem, P. A8-A9

Wesley Creek: idem, p. AlO

25. Horge Creek: Cobb and Mayfield, 1981 (OF 81-570A), P. A5

Sunshine Creek: idem, p. AlO

26. Arctic: Cobb and Mayfield, 1981 (OF 81-570A), p. A3

Dead Creek: idem, p. A5

27. Unnamed occurrence: Grybeck and Nelson, 1981 (MF-1176-F), $10 \mathrm{C} .55$

28. Unnamed occurrence: Grybeck and Nelson, 1981 (MF-1176-F), 10c. 63

29. Unnamed occurrences: Grybeck and Nelson, 1981 (MFml176-E), 1ocs. 1-3

30. Angiaak Pass: Grybeck and Nelson, 1981 (MP-1176-E), 10c. 15

tunawed occurrence: idem, loc. 18

31. Unnamed occurrences: Grybeck and Nelson, 1981 (MF-1176-F), 10cs. 23,25

32. Unnamed occurrence: Grybeck and Nelson, I981 (MF-1176-F), 10c. 30

33. Hune Fork: Cobb, 1981f (OP 81-732A), P. A8

34. Unnamed occurrences: Dillon and others, 1981 (AOF 133B), samples 218,480

35. Unnamed occurrences: Cobb, 1981E (OF 81-732A), P. Al9; Dillon and others, 1981 (AOF 133B), sample 80

36. Unnamed occurrence: Dillon and others, 1981 (AOF 133B), sample 199

37. Crevice Creek: Cobb, 1981f (OF 81-732A), P. A5

Unnamed occurrence: Dillon and others, 1981 (AOF 133B), gample 303

38. Unnamed occurrences: Cobb, 1981f (OF 81-732A), P. Al8; Dillon and others, 1981 (AOF 133B), samples 11,244

39. Unnamed occurrences: Cobb, 1981f (OE 81-732A), P. Al8; Dillon and others, 1981 (AOF 1338), sample 489

40. Rye Creek: Cobb, 1976a (OF 76-340), P. 150 


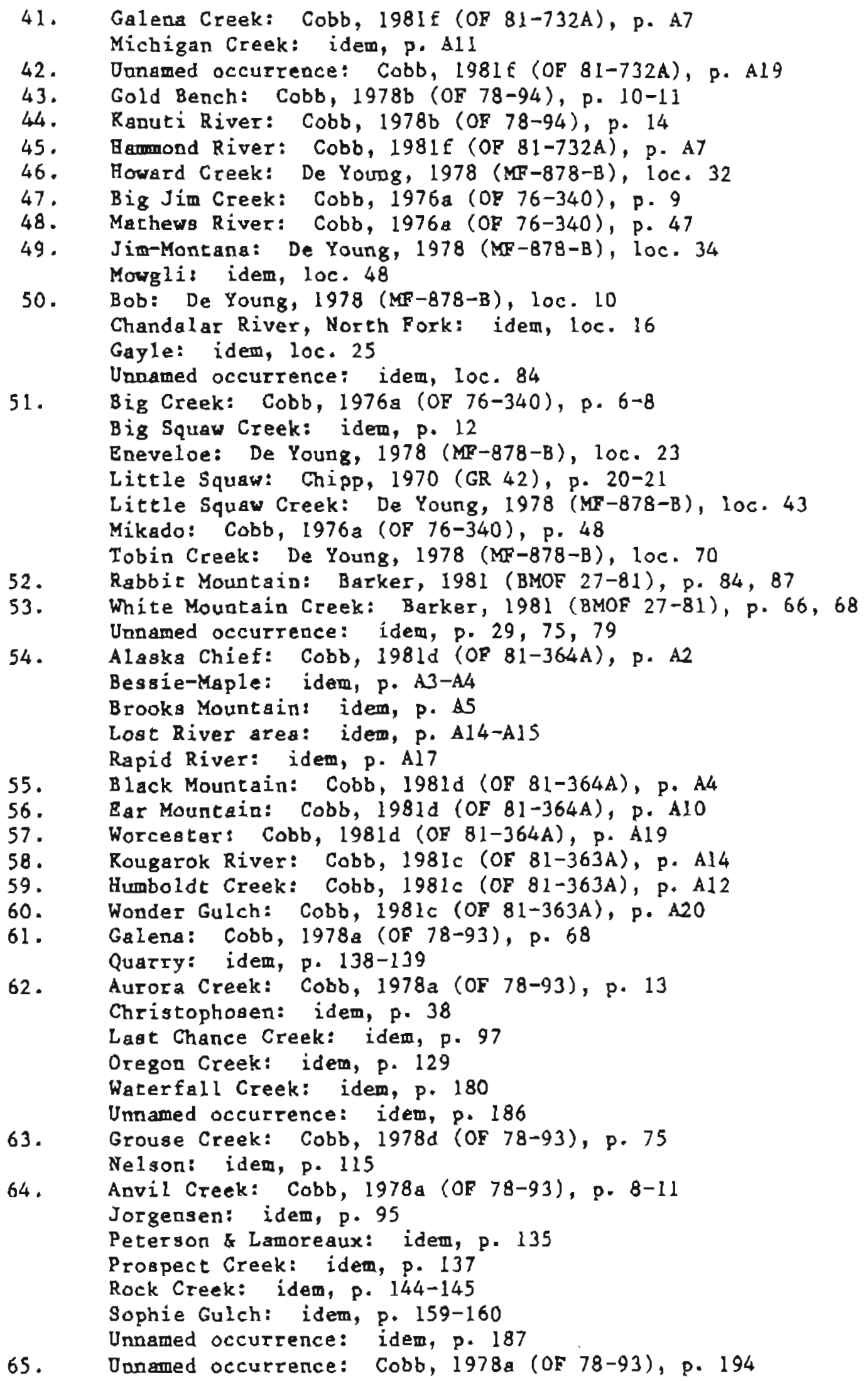




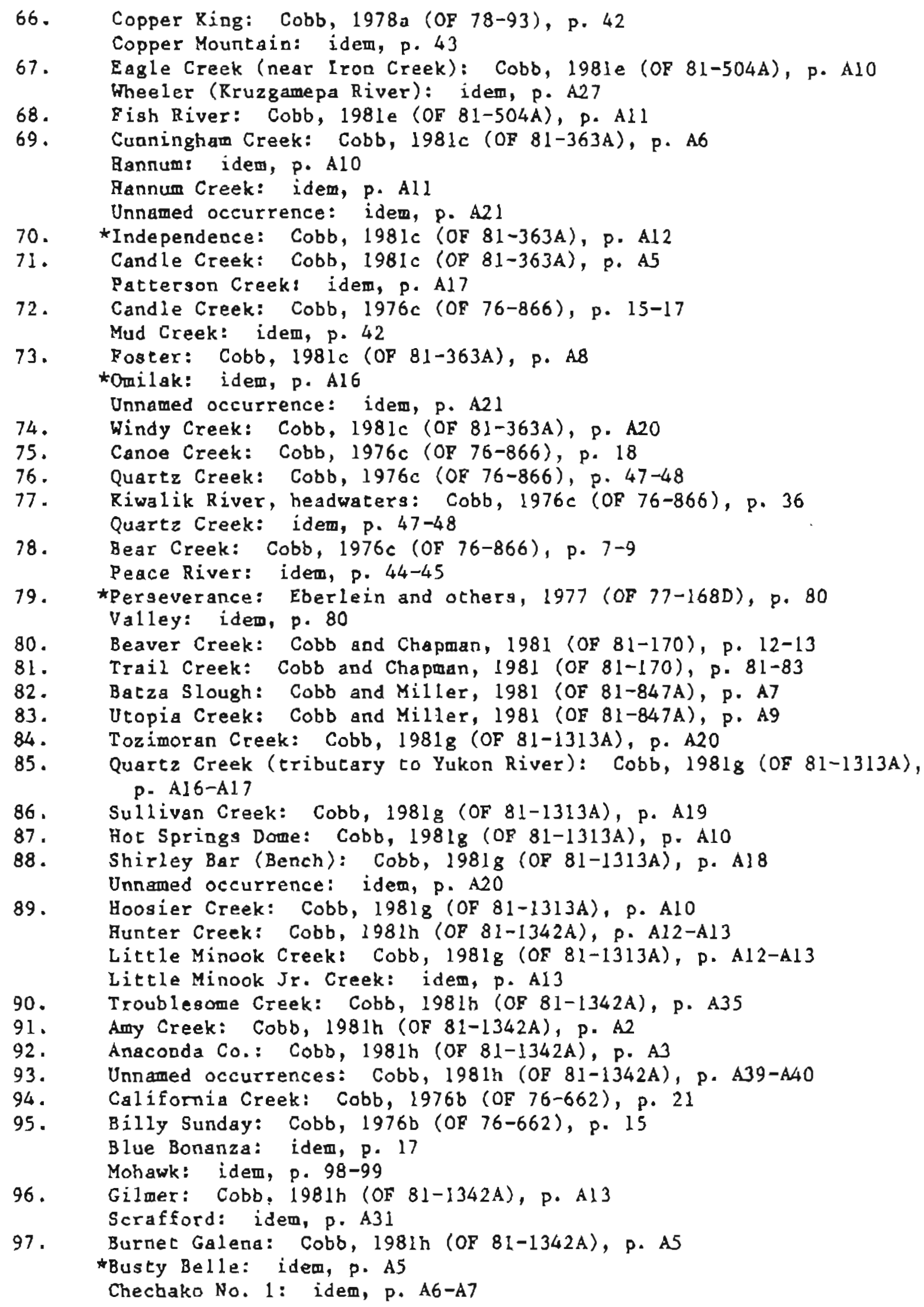


Cleary Hill: idem, p. A7-A8

GoepEert: idem, p. Al4

Independence: idem, P. Al9

Jackson: idem, p. Al9

Nightingale: idew, P. A25

Rainbow: idem, P. A29

Soo: idem, P. A31-A32

Wackwitz (Cleary Sumit): idem, p. A36

White Elephant: idem, p. A37

Woods: idem, p. A38-A39

98. Anne-Mary: Cobb, 198ih (OR 81-1342A), P. A3

Bobbie: idem, p. A4

Branholm-Jenking: idem, R. A4

Butler \& Petree: idem, p. A5

Excelsior: idem, p. Al1-Al2

Hi-Yu: idem, p. Al7

Homestake: idem, p. A17

Mizpah: idem, p. A23

Ohio: idem, p. A26

Whitehorse: idem, $p . A 37$

99. Hope Creek: Eberlein and otherg, (OF 77-168D), p. 21

100. Bonanza Creek: Eberlein and others, 1977 (OF 77-168D), p. 18

Independence Creek: idem, p. 21

Mammoth Creek: idem, p. 22

Miller House: idem, p. 23

101. Deadwood Creek: Eberlein and others, 1977 (OF 77-168D), p. 19

Switch Creek: idem, P. 24

102. Buckeye Creek: Cobb and Eberlein, 1980 (OF 80-1086), p. 8

Tenderfoot Creek: idem, p. 32-33

103. Unnamed occurrence: Cobb and Eberlein, 1980 (OF 80-1086), p. 39

104. Onnamed occurrence: Cobb and Eberlein, 1980 (OF 80-1086), p. 38

105. Copper Creek: Cobb, 1977 (OF 77-845), p. 29

106. My Creek: Cobb, 1977 (OF 77-845), p. 73

Ruby Silver: idem, p. 85

Unnamed occurrences: Foater and Clark, 1969 (OF 69-94), table 2, samples 122,123

107. Fourth of July Creek: Cobb, 1977 (OF 77-845), p. 51

108. Crooked Creek: Cobb, 1977 (OF 77-845), p. 30-31

109. Unnamed occurrences: Cobb, 1977 (OF 77-845), P. 112; Foster and Clark, 2969 (OF 69-94), table 2, sample 39

110. Franklin Creek: Cobb, 1977 (OF 77-845), p. 53-54

111. Dome Creek: Cobb, 1977 (OF 77-845), p. 36-37

112. Tiflighak Bay: Cabb, 1980 b (OF 80-909), p. 60

113. Powooiliak Point: Cobb, 1980b (OF 80-909), p. 58

Dnnamed occurrence: idem, p. 62

114. Unnamed occurrence: Cobb, $1980 \mathrm{~b}$ (OP 80-909), p. 64

115. Unnamed occurrence: Cobb, 1980b (OF 80-909), p. 65

116. *Golden Horn: Eberlein and others, 1977 (OF 77-168D), p. 55

Otter Creek: idem, p. 57-58

117. Unnamed occurrence: Schwab and others, 1981 (OF 80-811B), 10c. 50

118. Ozzna Creek: Cobb and Reed, 1981 (OF 81-1343A), P. A20-A21

Ozzna Creek tributary: idem, p. A21

Sheep Creek, Rat Fork: idem, p. A22

119. Smith Lake: Bundtzen and others, 1981 (AOF 149), p. 22, loc. 8 
Unnawed creek: Cobb and Reed, 1981 (OF 81-1343A), p. A23

120. Bowser Creek: Cobb and Reed, 1981 (OF 81-1343A), P. A19

Hippie Creek: idem, P. A2O

Hippie Creek, South Fork: idem, P. A2O

121. Shellbarger Pass: Cobb and Reed, 1980 (OF 80-884), p. 62

122. Boulder Creek: Cobb and Reed, 1980 (OF 80-884), P. 9

Hogback: idem, p. 34

J \& R: idem, p. 36

Mespelt: idem, p. 44

123. Gopher Creek: Cobb and Reed, 1980 (OF 80-884), p. 32

124. Greenback: Cobb, 1980a (OF 80-363), p. 46

Magnet: idew, p. 64

Old Sourdough: idem, p. 80

125. Galena Lode: Cobb, 1980a (OF 80-363), p. 35

Glacier Creek: idem, p. 36-37

126. Twin Hills: Cobb, 1980 \& (OF 80-363), p. 109

127. Moune Eielson: Cobb, 1980a (OF 80-363), p. 72-74

128. Alpha: Cobb, 1980a (OF 80-363), p. 5

Banjo: idem, p. 8-9

Bosart: idem, p. 11

Eureka Creek: idem, p. 26-27

Florence: idem, P. 29

Friday Creek: idem, p. 22

*Galena: idem, p. 33-34

*Gold Dollar: idem, p. 43

*Golden Eagle: idem, p. 44

Gold Ring: idem, p. 45

Hillside: idem, p. 49

Keystone: idem, p. 53

*Little Annie: idem, p. 55-57

Little Maud: idem, p. 59

Lucky Strike: idem, p. 63

* Marcha Q: idem, p. 66

Neveroweat: idem, p. 76-77

North Star (Friday Creek): idem, p. 78

Pennsylvania: idem, p. 81

Polly Wonder: idem, p. 84

*Red Top: idem, p. 87-88

Silver Pick: idem, P. 90-9l

Twenty-two Gulch: idem, p. 108

Water Level: idem, p. 111

Weiler: idem, p. 112

Unnamed occurrences: idem, p. 120, 133, 134, 136, 137

129. Arkangag: Cobb, 1980a (OF 80-363), p. 7

Glen: idem, p. 38

Glen Creek: idem, p. 39-40

Glen Creek divide: idem, p. 41

Glen Ridge No. 1: idem, p. 42

Humboldt: idem, p. 51

Lena: idem, p. 54

Lucky Jim: idem, p. 62

McGonogill: idem, p. 67

Mystery: idem, p. 75

North Star (Spruce Creek): idem, p. 79 
Pension: idem, p. 82

Ridgecop: idem, p. 89

Silver Hire: idem, p. 92

Yellow Creek: idem, p. 115

Unnamed occurrences: idem, p. 121,128

130. Unnamed occurrence: Cobb, 1980a (OF 80-363), p. 135

131. Unnamed occurrences near Chitsia Mountain: Cobb, 1980a (0F 80-363), P. 18, 130, 138; Cobb and Chapman, 1981 (OF 81-170), p. 5

132. Ready Cash: Cobb, 1978d (OF 78-1062), P. 67-68

133. *Golden Zone: Cobb, 2978d (OF 78-1062), p. 36-40

Loug Creek: iden, p. 50

Lookout Mountain: idem, p. 51

Riverside: idem, p. 69

134. Inly: Cobb and Csejtey, 1980 (OF 80-716), p. 20

135. Mint: Cobb and Csejtey, 1980 (OF 80-716), p. 26

136. Glory Creek: Cobb, 1978d (OF 78-1062), p. 34

137. Accident: Cobb, 1978d (OF 78-1062), P. 6

Lucky Top: idem, p. 54

White Creek: idem, p. 85-86

Yellowhorn: idem, p. 89

138. Bee Mining Co.: Cobb, 1979a (OF 79-238), p. 11

Rainbow Mourtain: idem, p. 60-61

139. Rainbow Mountain: Cobb, 1979a (OF 79-238), p. 60-61

140. McCumber Creek: Cobb, 1979a (OF 79-238), p. 46

141. Chistochina River, Middle Fork: Cobb, 1979a (OF 79-238), p. 20-21

142. Burns: Cobb, 1979f (OF 79-1247), p. 7

143. Indian: Cobb, 1979f (OF 79-1247), p. 15-16

Neversweat: idem, p. 21

The Dome: idem, $q, 28$

144. Gold-Quartz: Cobb, 1979f (OF 79-1247), p. 9

Silver Creek: idem, p. 23-24

Silver Shield: idem, p. 25

Unnamed prospect: idem, p. 31

145. Unnamed prospect: Cobb and Richter, 1980 (OF 80-927), p. 104

146. Onnamed occurrence: Cobb and Richter, 1980 (OF 80-927), p. 106

147. Nabesna: Cobb and Richter, 1980 (OF 80-927), p. 44-45

148. Unnamed grospect: Cobb and Richter, 1980 (OF 80-927), p. 95

Unnamed occurrence: idem, p. 97

149. Cross Creek: Cobb and Richter, 1980 (OF 80-927), P. 23

Unnamed occurrences: idem, p. 98,100

150. Fairplay: Cobb and Eberlein, 1980 (OF 80-1086), p. 46

151. Big Creek: Cobb and Eberlein, 1980 (OF 80-1086), p. 43

152. Bonanza Creek: Cobb and Richter, 1980 (OF 80-927), p. 9-10

Zrie: idem, p. 27

Unnamed occurrence: idem, p. 99

153. Eureka Creek: Cobb and Richter, 1980 (OF 80-927), p. 28. Noce:

May be across boundary in Yukon Territory.

154. Arrold: Eberlein and others, 1977 (OF 77-168D), P. 91

Disappointment Creek: idem, p. 92

155. Cobalt Creek: Hoare and Cobb, 1977 (OF 77-156), p. 66-67

Mission Creek: Eberlein and others, 1977 (OF 77-168D), p. 93

156. Bonanza Creek: Cobb and Reed, 1981 (OF 81-1343A), p. A8-A9

Bonanza rills: idem, p. A9

157. Rijik River: Cobb and Reed, 1981 (OP 81-1343A), P. A10 
Pass: idem, p. Al2

158. Rontrashibuna lake: Cobb and Reed, 1981 (OF 81-1343A), p. A10-All

159. Duryea: Cobb and Reed, 1981 (OF 81-1343A), Q. A4

160. Twin Lakes, west: Cobb and Reed, 1981 (OF 81-1343A), p. A13

161. Unnamed occurrence: Cobb and Reed, 1981 (OF 81-1343A), P. A17

162. Another River: Cobb and Reed, 1981 (OF 81-1343A), p. A14

163. Chilligan River: Cobb and Reed, 1981 (OF 81-1343A), P. Al4

West Chilligan: idem, P. Al5

164. Chilligan: Cobb and Reed, 1981 (OF 81-1343A), p. A14

Styx River: idem, p. Als

Unnamed occurrences: Cobb, 1979g (OF 80-86), p. 25; Cobb and Reed, $1981(\mathrm{OF}-1343 \mathrm{~A})$, P. Al 8

165. Dnnamed occurrence: Cobb and Reed, 1981 (OF 81-1343A), p. Al7

166. Jimmy Lake: Cobb and Reed, 1981 (OF 81-1343A), p. Als

167. Mount Estelle: Cobb, $1979 \mathrm{~g}$ (OF 80-86), p. 20

168. Skwentra River: Cobb, 1979g (OF 80-86), p. 23

169. Glass \& Heifner: Cobb, 1979h (OF 80-87), p. 15

170. Nukalaska: Cobb, 1979h (OF 80-87), p. 26

Sather: idem, p. 34

Skinner: idem, p. 37

171. Goyne: Cobb, 1979h (OF 80-87), p. 16-17

Hatcher: idem, p. 18

Johnston \& Degan: idem, p. 19

Sonny Fox: idem, p. 38-39

172. Fera: Cobb, 1979d (OF 79-1095), p. 36-37

Galena-Gold: idem, p. 39

Gold Cord: idem, p. 43-45

Independence: idem, p. 63-65

Lucky Stot: idem, p. 88-89

Mabel: idem, p. 91-92

Maxion Twin: idem, p. 94

Martin: idem, p. $97-98$

Rae: idem, p. 128

Schroff-O'Neil: idem, p. 138

Stiles: idem, p. 149

173. Unnamed occurrence: Cobb, 1979d (OF 79-1095), P. 168

174. Myers: Cobb, 1979d (OF 79-1095), p. 114

175. Indian: Cobb and Tysdal, 1980 (OF 80-621), p. 112

176. Coon \& Plowman: Cobb and Tysdal, 1980 (OF 80-621), P. 60

Downing: idem, P. 74

Gold Stamp: idem, P. 93

Hirshey \& Carlson: idem, p. 104

Renai Star: idem, p. 126

Nearhouse: idem, p. 167

Robinson \& Bowman: idem, P. 198

177. Lucky Strike: Cobb and Tysdal, 1980 (OF 80-621), p. 145

Teddy Bear: idem, p. 233

Unnamed occurrences: idem, p. 259, 260

178. Alaska Oracle: Cobb and Tysdal, 1980 (OF 80-621), p. 24

Fresno Creek: idem, p. 83

Gilpatrick: idem, p. 86

Iron Mask: idea, p. 116

Swetmann: idem, p. 231

179. Quartz Creek: Cobb and Tysdal, 1980 (OF 80-621), p. 187 
180. Peters Creek: Cobb, 1979d (OF 79-1095), P. 121

181. Eagle River: Cobb, 1979d (OF 79-1095), p. 32

182. Agostino: Cobb, 1979d (OF 79-1095), p. 5-6

Bahrenberg: idem, p. 12

Breaner: idem, $p .21$

Jewel: idem, p. 67

Unnamed occurrence: idem, p. 167

183. Bird Point: Cobb and Tysdal, 1980 (OF 80-621), p. 38

Sawnill Creek: idem, p. 201

184. Seward Gold: Cobb and Tysdal, 1980 (OF 80-621), p. 206

185. Califoraia-Alaska: Cobb and Tygdel, 1980 (OF 80-621), p. 45

Renai-Alaska: idem, p. 124

Skeen-Lechner: idem, P. 214

186. Brown Besr: Cobb and Tysdal, 1980 (OF 80-621), p. 42

Porcupine: idem, p. 181

Primrose: idem, p. 186

Seward Bonanza: iden, p. 205

387. Mile Seven: Cobb and Tysdal, 1980 (OF 80-621), p. 157

Mizpah: idem, p. 160

Schoonover: idem, p. 202

188. Mile Four: Cobb and Tygda1, 1980 (OF 80-621), p. 156

Northera Light: idem, P. 171

Resurrection Bay Mining Co.: idem, p. 192

189. Unnamed occurrence: Cobb and Tysdal, 1980 (OF 80-621), p. 22

190. Billings Glacier: Hoekzema and Sherman, 1981 (BMOF 141-81)

Golden Giant: Cobb and Tysdal, 1980 (OF 80-621), p. 89

Hillside: idem, p. 103

191. Durklee \& Reilly: Cobb and Tysdal, 1980 (OF 80-621), p. 75

Humer: idew, p. 110

Tomboy: iden, p. 238

192. Banaer: Cobb and Tysdal, 1980 (OF 80-621), P. 28

George \& McParland: idem, p. 85

Granite: idem, p. 95

Berman \& Eaton: idem, p. 102

Sweepstake Mining Co.: idem, p. 230

Yakima: idem, p. 250

Unnamed occurrence: idem, p. 261

193. Black \& Bogan: Cobb, 1979 (OF 79-1095), p. 17

194. Mitchell \& Myers: Cobb, 1979d (OP 79-1095), p. 108

Reiter \& Olson: idem, p. 134

Simonton Millg: idem, p. 142

Walters, Brasslin \& Atkinson: idem, p. 156

195. Thomas-Culross: Cobb and Tysdal, 1980 (OF 80-621), p. 235

196. Kavanaugh \& Boon: Cobb and Tysdal, 1980 (OF 80-621), p. 123

197. Conley \& McChesney: Cobb and Tysdal, 1980 (OF 80-621), p. 58

Golden Wonder No. 1: idem, p. 90

Nugget: idem, p. 173

198. Jackpot Bay: Cobb and Tysdal, 2980 (OF 80-621), p. 117

199. Latouche: Cobb and Tysdal, 1980 (OF 80-621), p. 137-138

Reynolds-Alaska Development Co: idem, P. 196

200. Nelchina Glacier: Henning and Pessel, 1980 (AOF 126)

201. Mayfield: Cobb, 1979e (OF 79-124I), p. 79

202. Cameron-Johnson: Cobb, 1979e (OF 79-1241), p. 27

Gold King: idem, p. 55 


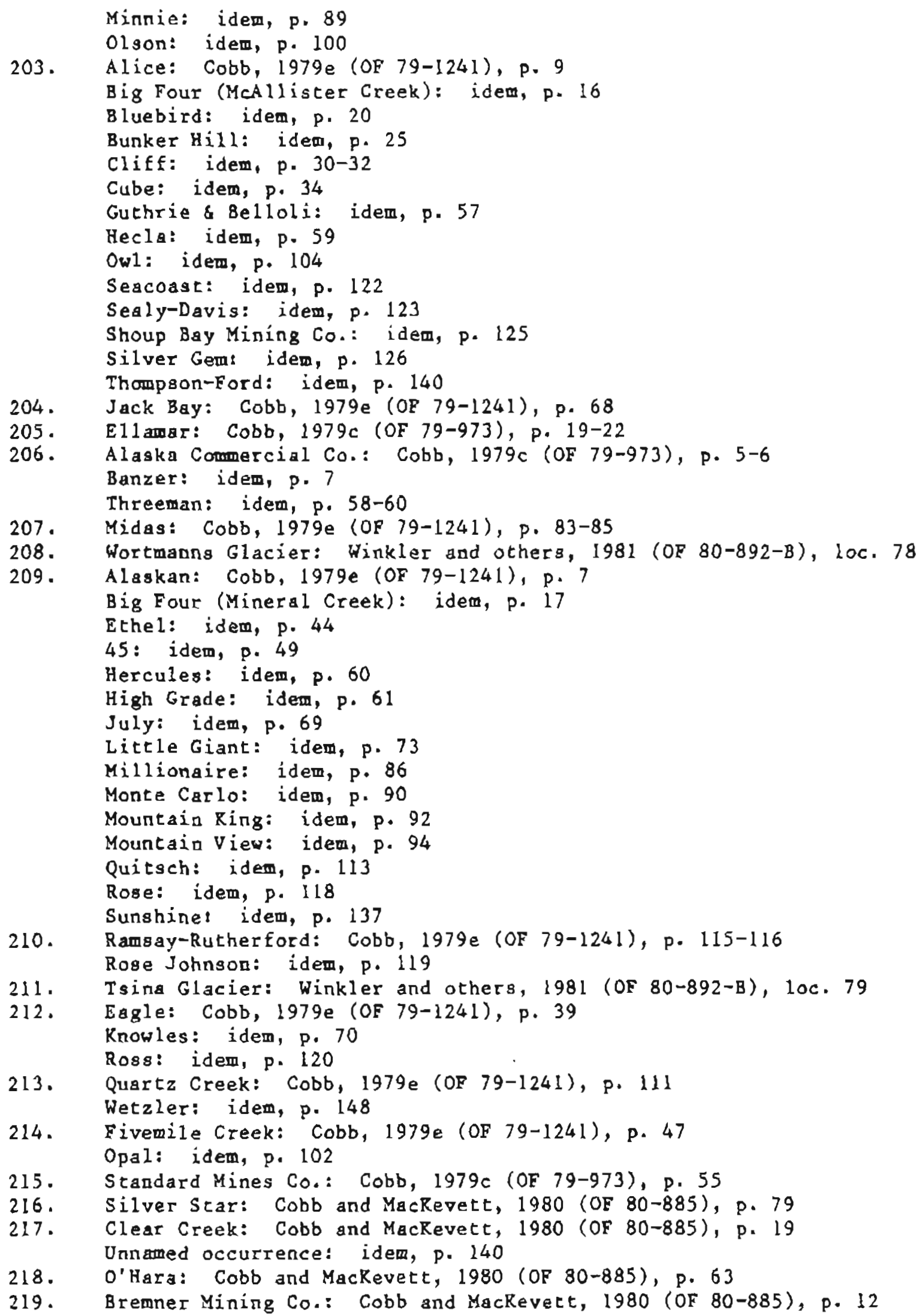


220. Rennecott mines: Cobb and Mackevett, 1980 (OF 80-885), p. 41-43

221 .

222 .

223.

224.

225 .

226.

227 .

228 .

229.

230 .

231.

232 .

233.

234 .

235.

236.

237 .

238.

239.

240.

241 .

242 .

243.

244.

245 .

Portage: idem, p. 56

246. Hawk Inlet: Berg and others, 1981 (OF 81-122), p. 58

247. Greens Creek: Berg and others, 1981 (OF 81-122), p. 58

Memonoth: idem, p. 58

248. Comer: Berg and others, 1981 (OF 81-122), p. 43

Frenoming: idem, p. 45

Jualin: idem, p. 44

Rensington: idem, p. 43

249. California: Berg and otherg, 1981 (OF 81-122), p. 47

Gold Standard: idem, p. 47

250. Aurora Borealis: Berg and others, 1981 (OF 81-122), p. 47

Bessie: idem, p. 47

Black Chief: idem, p. 48

Cascade: idem, p. 48

Dividend: idem, p. 48

Eagle River (Amalga): idem, P. 49 
E Pluribus Unum: idem, p. 48

251. Mitchell \& McPherson: Berg and others, 1981 (OF 81-122), p. 49

St. Louis: idem, 9.49

Windfall Creek: idem, p. 50

252. Mendenha11: Berg and others, 1981 (OF 8I-122), p. 50

253. Lemon Creek: Berg and others, 1981 (OF 81-122), p. 51

Hagner: idem, p. 51

254. *Alaska-Juneau: Cobb, 1978c (OF 78-374), p. 15-19

Alagka-Juneau dump: idem, p. 20

Anderson: Berg and others, 198l (OF 8l-122), p. 55

C1ark: iderl, p. 54

Ebner: Cobb, 1978c (OF 78-374), p. 51-52

*Pergeverance: idem, P. 107-108

Reggan: Berg and others, I981 (OF 81-122), p. 49

Silver Queen: idem, $\mathrm{p} .54$

*Treadwell mines: idem, p. 53

Yakima: idem, p. 53

255. Alaska Treasure: Berg and ochers, 1981 (OF 81-122), P. 56

Middle Peak: idem, p. 55

256. Litestone Inlet: Berg and ochers, 1981 (OF 81-122), p. 126

257. Taku River: Berg and others, 1981 (OF 81-122), p. 126

258. Whiting River: Berg and others, 1981 (OF 81-122), p. 126

259. Apex-E1 Nido: Berg and others, 1981 (OF 81-122), p. 99

260. Cobol (Pints Bay): Berg and others, 1981 (OF 81-122), P. 99

Lake Elfendahl: idem, p. 100

261. Koby: Berg and others, 1981 (OF 81-122), p. 101

Whitestripe: Still and Weir, 1981 (BMOF 89-81), p. 68-70

262. Congress: Still and Weir, 1981 (BMOF 89-81), table 8 , loc. 8

263. Chichagoff: Berg and otherg, 1981 (OF 81-122), p. 103

Hirst-Chichagof: idem, p. 102

Jumbo: idem, p. 103

Lake Aana: idem, p. 105

Lillian \& Princella: idem, p. 104

Lucky Shot: idem, P. 104

Vern Poiat: Still and Weir, 1981 (BMOF 89-81), table 7, loc. 47

Unnamed occurrence: idem, cable 7 , loc. 40

264. Cobol (S1ocum Arm): Berg and others, 1981 (OF 8l-122), p. 106

Falcon Arm: idem, p. 105

265. Billy Basin: Berg and others, 1981 (OF 81-122), p. 107

266. Pregident: Berg and others, 1981 (OF 81-122), p. 109

267. Keku Islet: Berg and others, 1981 (OF 8 -122), p. 94

268. Port Kalmesbury: Gerg and others, 1981 (OF 81-122), p. 95

269. Point St. Albans: Berg and others, 1981 (OF 81-122), p. 90

270. Dry Pass: Berg and otherg, 1981 (OF 81-122), p. 90

271. Taylor Creek: Berg and others, 1981 (OF 81-122), p. 86

272. "Halobia locality": Berg and others, 1981 (OF 81-122), p. 91

273. Hactie: Berg and others, 1981 (OF 81-122), p. 88

Helen S.: idem, p. 87

Maid of Mexico: idem, p. 87

274. "BP adie": Berg and others, 1981 (OF 81-122), p. 92

"Hydropie": idem, p. 92

"Lost Zarembo": idem, P. 92

275. Sweetheart Lake: Berg and others, 1981 (OF 81-122), p. 120

Sweetheart Ridge: idem, p. 121 
Tracy Arm: idew, p. 121

276. Sumdum: Berg and others, 1981 (OF 81-122), p. 122

277. Point Agtley: Berg and others, 1981 (OF 81-122), p. 122

278. Holkham Bay: Berg and others, 1981 (OF 8I-122), p. 123

Portland: idem, p. 123

Sumdum Chief: idem, P. 123

279. Bluebird: Berg and others, 1981 (OF 81-122), p. 123

Sulphide: idem, p. 124

Windham Bay: idem, p. 124

280. Unamed occurrence: Berg and otbers, 1981 (OF 81-122), p. 124

281. Colp \& Lee: Berg and others, 1981 (OF 81-122), p. 125

282. Thomas Bay: Berg and others, 1981 (OP 81-122), p. 87

283. Berg Basin: Berg and athers, 1981 (OF 81-122), p. 89

Copper Ring: idem, p. 1

Glacier Basin: idem, p. 89

Groundhog Basin: idem, p. 88

*Lake: idem, P. 88

284. Edelweiss: Berg and others, 1981 (OF 81-122), p. 3

Galena: idem, $p .3$

Glacier: idem, p. 2

Greenpoinc: idem, p. is

*Heckla: idem, p. 3

Jumbo: idem, p. 3

Marmot: idem, p. 3

285. Blasher: Berg and others, 1981 (OF 8I-122), p. 5

Cathedral: idem, p. 4

Chickamin: idem, p. 4

Double Anchor: idem, p. 4

Engineer: idem, p. 6

Evening Star: idem, p. 7

Homescake: idem, $p .7$

Gume l: idem, p. 6

Hyder Lead: idem, p. 5

Ibex: idem, $P .7$

Jumbo: idem, p. 6

Juneau: idem, p. 5

Reno: idem, p. 5

Lake: idem, p. 5

Lakeside: idem, p. 5

Liberty: idem, p. 7

Marietra: idem, p. 4

Morning: idem, p. 5

North Star: idem, p. 6

Nothiger: idem, p. 7

Silver Bell: idem, p. 6

Silver Coin: idem, p. 7

Silver Ring: idem, p. 4

Silver Star: idem, p. 7

Stampede (Dugas): idem, p. 4

Sunset: idem, p. 6

Swendings Greenpoint: idem, p. 5

Texas Discoverg: idem, p. 7

286. Alaska-Premier: Berg and otherg, 1981 (OF 81-122), p. 9

Bartholf: idem, p. 8 


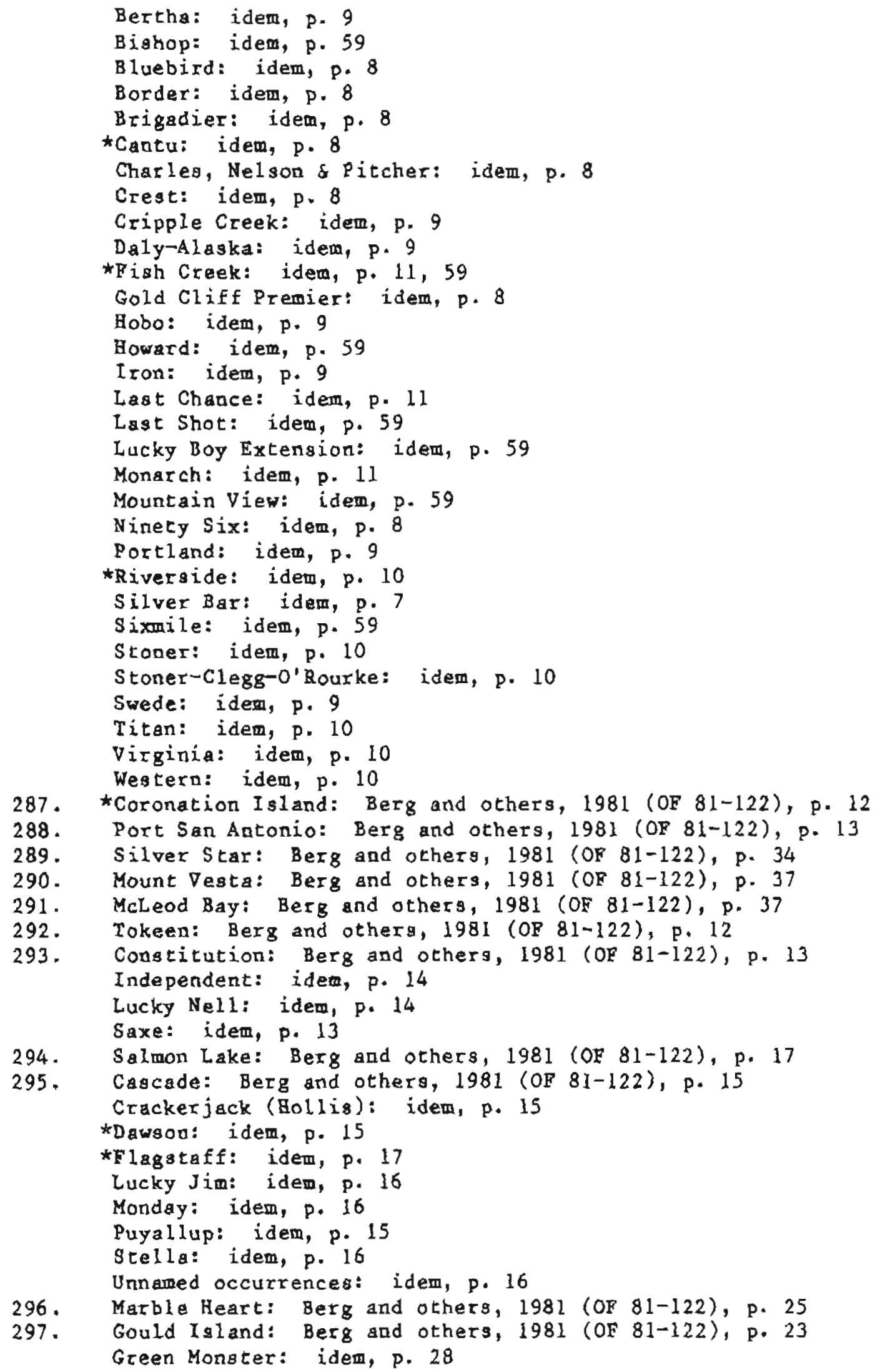


Unnamed occurrence: idem, p. 25

298. Marion: Berg and others, 1981 (OF 81-122), p. 29

299. Hope: Berg and others, 1981 (OF 81-122), p. 29

Lucky Boy: idem, p. 29

*Moonshine: idem, p. 28

Research: idew, p. 28

300. Kid: Berg and others, 1981 (OF 81-122), P. 30

O.R.: idem, p. 32

Salmon: idem, p. 32

Valparaiso: idem, p. 31

301. Niblack: Berg and others, 1981 (OF 81-122), p. 33 Westlake: idem, p. 33

302. Bokan Mountain: Berg and others, 1981 (OF 81-122), p. 38

303. *Nelson \& Tift: Berg and others, 1981 (OF 81-122), p. 97

304. Gold Mountain: Cobb and Elliott, 1980 (OF 80-1053), p. 45

Gold Standard: Berg and others, 1981 (OF 81-122), p. 35, 61

Helm Bay King: idem, p. 36

Rainy Day: Cobb and Elliott, 1980 (OF 80-1053), P. 89

305. Londevan: Cobb and Elliott, 1980 (OF 80-1053), p. 68

*Mahoney: idem, p. 71

Peterson: idem, p. 84

306. Baltic Star: Cobb and Eliliott, 1980 (of 80-1053), p. 11

Gold Banner: idew, p. 43

Goo Goo: idem, p. 48

Lake: idem, P. 62

Massachusetts: idem, p. 74

Sea Breeze: idem, p. 94

Sealevel: idem, p. 96

Tyee: idem, p. 104

307. Moth Bay: Cobb and Elliott, 1980 (OF 80-1053), p. 77

308. Birdaeye: Cobb and Elliott, 1980 (OF 80-1053), p. 15

Gold Stream: idem, p. 47

309. Driest Point: Cobb and Elliott, 1980 (OF 80-1053), p. 36

Nadzaheen Cove: idem, p. 80

Unnamed occurrences: idem, p. 130, 134, 135

310. Blunt Mountain: Cobb and Elliott, 1980 (OF 80-1053), p. 20

Crab Bay: Berg and others, 1981 (OF 81-122), p. 69, loc. 146

Unnamed occurrences: Cobb and E11iott, 1980 (OF 80-1053), p. 128, 131

311. Gnat: Cobb and E11iott, 1980 (OF 80-1053), p. 42

\section{REEERENCES CITED}

Barker, J. C., I981, Mineral investigations in the Porcupine River drainage,

Alasks: U.S. Bureau of Mines Open-File Report 27-81, $189 \mathrm{p}$.

Berg, H. C., Decker, J. B., and Abrameon, B. S., 1981, Metallic mineral deposits of southeastern Alaska: U.S. Geological Survey Open-File Report $81-122,136 \mathrm{p}$.

Bundtzen, T. K., Kline, J. T., and Clough, J. G., 1982, Preliminary geology of McGrath B-2 quadrangle, Alaska: Alagka Division of Geological and

Geophysical Surveys Open-File Report 149, 22 p., I sheet, acale 1:40,000.

Chipp, E. R., 1970, Geology and geochemistry of the Chandalar area, Brooks Range, Alaska: Alaska Division of Mines and Geology Geologic Report 42, 39 P. 
Cobb, E. H., 1976a, Summary of references to mineral occurrences (other than mineral fuers and construction materials) in the Chandalar and Wiseman quadrangles, Alaska: U.S. Geological Survey Open-File Report 76-340, 205 P.

1976b, Sumary of references co mineral occurrences (other than mineral fuels and construction aaterials) in the Fairbanks qusdrangle, Alagka: 0.S. Geological Survey Open-File Report 76-662, 174 p.

1976c, Summary of references to mineral occurrences (other than mineral fuels and construction materials) in the Candle, Holy Cross, Norton Bay, Nulato, and Unalakleet quadrangles, Alaska: U.S. Geological Survey OpenFile Report 76-866, 102 p.

1977, Sumary of references to mineral occurrences (other than mineral Fuels and construction materials) in the Eagle quadrangle, Alaska: U.S. Geological Survey Open-File Report 77-845, 122 p.

1978a, Sumary of references to mineral occurrences (other than mineral fuels and construction materials) in the Nome quadrangle, Alaska: U.S. Geological Survey Open-File Report 78-93, 213 p.

1978b, Summsry of references to mineral occurrences (other than mineral fuels and congtruction materials) in the Beqver, Bettles, and Medfra quadrangles, Alagka: U.S. Geological Survey Open-File Report 78-94, 55 p.

$1978 \mathrm{c}$, Summary of references to mineral occurrences (other than mineral fuels and construction materials) in the Juneau quadrangle, Alaska: U.S. Geological Survey Open-File Report 78-374, 155 p.

$1978 d$, Sumary of references to mineral occurrences (other than mineral fuels and construction materials) in the hesiy quadrangle, Alaska: U.S. Geological Survey Open-File Report 78-1062, $112 \mathrm{p}$ -

1979a, Sumary of references to mineral occurrences (other than mineral fuels and conscruction materials) in the Mount Rayes quadrangle, Alagka: U.S. Geological Survey Open-File Report 79-238, 140 p.

1979b, Sumary of references to mineral occurrences (other than mineral fuels and construction materials) in the Afogmak, Karluk, Kodiak, and Trinity Ialands quadrangles, Alaska: U.S. Geological Survey Open-File Report $79-860,47 \mathrm{p}$.

$1979 \mathrm{c}$, Sumary of references co mineral occurrences (ocher than mineral Euels and congruction materials) in the Cordova quadrangle, Alagka: U.S. Geological Survey Open File Report 79-973, $74 \mathrm{p}$.

$1979 \mathrm{~d}$, Sumary of references to mineral occurrences (other than mineral fuels and construction materials) in the Anchorage quadrangle, Alaska: U.S. Geological Survey Oper-File Report 79-1095, $183 \mathrm{p}$.

$1979 e$, Sumary of references to mineral occurrences (other then mineral fuels and construction materials) in the Valdez quadrangle, Alaska: U.S. Geological Survey Open-File Report 79-1241, $166 \mathrm{p}$. 
$1979 \mathrm{f}$, Summary of references to mineral occurrences (ocher than mineral fuels and construction materials) in the Gulkana quadrangle, Alaska: U.S. Geological Survey Open-File Report 79-1247, 36 p.

$1979 \mathrm{~g}$, Summary of references to mineral accurrences (other than mineral fue is and conscruction materials) in the Kenai and Tyonek quadrangles, Alagka: 0.5 . Geological Survey Open-Eile Report 80-86, 36 p.

$1979 \mathrm{~h}$, Summary of references to mineral occurrences (other than mineral fuels and construction materials) in the Seldovia quadrangle, Alaska: U.S. Geological Survey Open-File Report 80-87, $47 \mathrm{p}$.

$1980 \mathrm{a}$, Sumary of references to mineral occurrences (other than mineral Fuels and construction materials) in the Mount McKinley quadrangle, Alaska: O.S. Geological Survey Open-File Report 80-363, 150 p.

$1980 \mathrm{~b}$, Sumaries of data on and lists of references to metallic and selected nometalize mineral deposits in fifteen quadrangles, in southwegtern and west-central Alaska (Atka, Attu, Bristol Bay, Chignik, Cold Bay, Hagemeister Island, Mount Xatmai, Naknek, Port Moller, Rat Islands, Saint Lawrence, Stepovak Bay, Ugashik, Unalaska, Unimak): U.S. Geological Survey Open-File Report 80-909, $103 \mathrm{p}$.

$1981 a$, Sumaries of data on and lists of references to metallic and gelected nometalic mineral occurrences in the Skagway quadrangle, Alaska, Supplement to Open-File Report 78-316; Part A - Sumaries of data to January 1, 1980: U.S. Geological Survey Open-File Report 81-82A, P. A1-AlO.

$1981 \mathrm{~b}$, Sumarieg of data on and listg of references to metallic and selected nometalic mineral occurrences in the Mount Fairweather quadrangle, Alagka, Supplement to Open-File Report 78-316; Part A -Sumaries of data to January 1, 1980: U.S. Geological Survey Open-File Report 81-249A, P. A1-A20.

$1981 \mathrm{c}$, Sumaries of data on and lists of references to metallic and selected nonmetallic mineral occurrences in the Bendeleben quadrangle, Alaska, Supplement to Open-File Report 75-429; Part A -- Summaries of data to January 1, 1980: 0.S. Geological Survey Open-File Report 81-363A, P. AlA25.

1981d, Summaries of data on and listg of references to metallic and selected nometallic mineral occurrences in the Teller quadrangle, Alaska, Supplement to Open-File Report 75-587; Part A -- Sumaries of data to January 1, 1980: U.S. Geological Survey Open-File Report 81-364A, P. AlA25.

1981 e, Sumaries of data on and 1 ists of references to metallic and selected nometallic mineral occurrences in the Solomon quadrangle, Alaska, Supplement to Open-File Report 78-181; Part A -- Sumaries of data to January I, 1981: U.S. Geological Survey Open-File Report 81-504A, P. AlA30. 
$1981 \mathrm{f}$, Sumaries of data on and lists of references to metallic and selected nonmetallic mineral occurrences in the Wiseman quadrangle, Alaska, Supplement to Open-File Report 76-340; Part A - Sumaries of data to January 1, 1981: O.S. Geological Survey Open-File Report 81-732A, P. AIA21.

$1981 \mathrm{~g}$, Summaries of data on and lists of references to metallic and selected nonetallic miveral occurreaces in the Tanana quadrangle, Alaska, Supplement to Open-File Report 77-432; Part A -- Sunmaries of data to June 1, 1981: U.S. Geological Survey Open-File Report 81-1313A, P. A1-A23.

$1981 \mathrm{~h}$, Sumaries of data on and 1ists of references to metallic and selected nonmetallic mineral occurrences in the Livengood quadrangle, Alagka, Supplement to Open-File Report 76-819; Part A -- Sumaries of data to August 1, 1981: D.S. Geological Survey Open-File Report 81-1342A, P. Al$\Delta 48$.

Cobb, E. H., and Chapman, R. M., 198I, Mineral occurrencea (other than mineral fuels and construction materials) in the Kantishna River and Ruby quadrangles, Alaska: U.S. Geological Survey Open-File Report 81-170, 94 p.

Cobb, E. B., and Crejtey, Bela, Jr., 1980, Sumaries of data on and lists of references to metallic and selected nonmetallic mineral deposits in the Talkeetna Mountains quadrangle, Alaska: U.S. Geological Survey Open-File Report 80-716, 63 p.

Cobb, E. H., and Eberleir, G. D., 1980, Sumaries of data an and 1 ists of references to metallic and selected nonmetallic mineral deposits in the Big Delta and Tanacross quadrangles, Alaska: U.S. Geological Survey Open-File Report 80-1086, $76 \mathrm{p}$.

Cobb, E. K., and Elliott, R. L., 1980, Summaries of data on and 1ists of references to metallic and selected nonmetallic mineral deposits in the Retchikan and Prince Rupert quadrangles, Alaska: U.S. Geological Survey Open-File Report 80-1053, 156 p.

Cobb, E. H., and Mackevett, E. M., Jr., 1980, Summaries of data on and lists of references to metallic and selected nonmetallic mineral deposits in the McCarthy quadrangle, Alaska: U.S. Geological Survey Open-File Report 80$885,156 \mathrm{p}$.

Cobb, E. R., and Mayfield, C. F., 1981, Sumaries of data on and lists of references to metallic and selected nonmetallic mineral occurrences in the Amblex River quadrangle, Alaska, Supplement to Open-File Report 75-628; Part A - - Summaries of data to January 1, 1981: D.S. Geological Survey Open-File Report 8L-570A, p. Al-Al3.

Cobb, E. H., Mayfie1d, C. F., and Brogge, W. P., 1981, Sumaries of data on and lists of references to metallic and selected nonmetallic mineral occurrences in eleven quadrangles in northera Alagka, Supplement to Open-File Report $75-$ 628; Part A -- Sumaries of data to January 1, 1981: U.S. Geological Survey Open-File Report 81-767A, p. A1-A24. 
Cobb, E. H., and Miller, T. P., 1981, Summaries of data on and lists of references to metallic and selected nometallic mineral occurrences in the Rughes, Kotzebue, Melozitna, Selawik, and Shungnak quadrangles, west-central Alaska, Supplement to Open-File Report 75-627; Rart A - Sumaries of data to January 1, 1981: U.S. Geological Survey Open-File Report 81-847A, P. A1A14.

Cobb, E. H., and Reed, B. L., 1980, Summaries of data on and lists of references to metallic and selected nometallic mineral deposits in the Talkeetna quadrangle, Alaska: U.S. Geological Survey Open-File Report 80-884, 106 p.

1981, Sumaries of data on and lista of references to metallic and selected nonmetallic mineral occurrences in the Iliamna, Lake Clark, Lime Hills, and MeGrath quadrangles, Alaska, Supplement to Open-File Report 786-485; Part A - Summaries to January 1, 1981: U.S. Geologieal Survey Open-File Report 81-1343A, P. Al-A25.

Cobb, E. H., and Richter, D. B., 1980, Summaries of data on and lists of references to metallic and selected nanmetallic mineral deposits in the Nabesa quadrangle, Alaska: U.S. Geological Survey Open-File Report 80-927, 116 g.

Cobb, E. H., and Tysdal, R. G., 1980, Summarieg of data on and lists of references to metallic and selected nometallic mineral deposits in the Blying Sound and Seward quadrangles, Alasika: U.S. Geological Sutveg OpenFile Report 80-62I, $284 \mathrm{p}$.

Detra, D. E., 1977, Delineation of an anomalous lead-zinc area in the Philip Smith Mountaina A-2 quadrangle, Alaska: U.S. Geological Survey Open-File Report 77-223, $11 \mathrm{p}$.

De Young, J. H., Jr., 1978, Mineral resources map of the Chandalar quadrangle, Alaska: U.S. Geological Survey Miscellaneous Field Studies Map MF-878-B, 2 sheets, scale $1: 250,000$.

Dillon, J. T., Moorman, M. A., and Lueck, Larry, 1981, Geochemical reconaissance of the southwest Wiseman quadrangle; summary of data on rock samples: Alaska Division of Geological and Geophysical Surveys Open-File Report 133B, $164 \mathrm{p}$.

Eberlein, G. D., Chapman, R. M., Foster, H. L., and Gassaway, J. S., 1977, Map and table describing known metalliferous and selected nonmetall iferous mineral deposits in central Alagka: U.S. Geological Survey Open-File Report 77-168D, $132 \mathrm{p.}+$ map, scale $1: 1,000,000$.

Ellersieck, I. F., Jansong, Oldis, Mayfield, C. F., and Tailleur, I. L., 1982, The Story Creek and Whoopee Creek lead-zinc-silver occurrences, western Brooks Range, Alaska, in Coonrad, W. L., ed., The United States Geological Survey in Alaska: Accomplishments during 1980: U.S. Geological Survey Circular 844 , p. $35-38$.

Foster, R. L., and Clack, S. H. B., 1969, Analyses of gtream-sediment and rock samples from the Fortymile area, Eagle quadrangle, Alaska: U.S. Geological Survey Open-File Report 69-94, 10 p. + 96 p. tabular material. 
Grybeck, Donald, 1977, Known mineral deposits of the Brooks Range, Alaska: U.S. Geological Survey Open-File Report 77-166C, 45 p. + mep, scale 1:1,000,000.

Grybeck, D. J., and Nelson, S. W., 1981, Mineral deposit map of the Survey Pass quadrangle, Brooks Range, Alaska: U.S. Geological Survey Miscellaneous Field Studies Map MF-1176-F, scale 1:250,000.

Henning, M. W., and Pessel, G. H., 1980, Reconnaissance geology of the Nelchina Glacier deposit, north-central Chugach Mountains: Alaska Division of Geological and Geophysical Surveys Open-File Report 126, 5 p.

Hoare, J. M., and Cobb, E. H., 1977, Mineral occurrences (other than mineral fuels and construction materials) in the Bethel, Goodnews, and Russian Mission quadrangles, Alagka: O.S. Geological Survey Open-File Report 77$156,98 \mathrm{p}$.

Hoekzema, R. B., and Sherman, G. E., 1981, Billings molybdenum-copper occurrence, Whittier, Alaska: D.S. Bureau of Mines Open-File Report 141-81, $27 \mathrm{p}$.

Jansons, Uldis, and Paxke, M. A., 1981, 1978 mineral investigations in the Misheguk Mountain and Howard Pass quadrangles, Alaska: U.S. Geological Survey Open-File Report 26 -81, $195 \mathrm{p}$.

Schwab, C. E., Patton, W. W., Jr., and Moll, E. J., 1981, Mineral occurrence mop of the Medfra quadrangle, Alaska: U.S. Geological Survey Open-File Report $80-811 \mathrm{~B}, 2$ sheets, scale $1: 250,000$.

Still, J.C., and Weir, K. R., 1981, Mineral land assessment of the west portion of western Chichagof Island, southeast Alaska: U.S. Bureau of Mines OpenFile Report 89-81, $168 \mathrm{p}$.

Tripp, R. B., and Decra, D. E., 1980, Map showing mineralogic data for selected minerals in nonmagnetic heavy-mineral concencrates of gtream sediments in the Chignik and Sutwik Is land quadrangles, Alaska: U.S. Geological Survey Miscellaneous Field Studies Map MF-1053-I, 2 sheets, scale 1:250,000.

Wilson, F. H., 1980, Late Mesozoic and Cenozoic tectonics and the age of porphyry copper prospects, Chignik and Sutwik Island quadrangles, Alaska Peninsula: U.S. Geological Surveg Open-File Report $80-543$, viii +94 p. +5 pls.

Winkler, G. R., Miller, R. J., Mackevett, E. M., Jr., and Holloway, C. D., 1981, Map and summary table describing mineral deposits in the Valdez quadrangle, southern Alagka: U.S. Geological Survey Open-File Report 80-892-B, 2 sheets, scale $1: 250,000$. 